\title{
AMERICAN FOUNDING SON: JOHN BINGHAM AND \\ THE INVENTION OF THE FOURTEENTH \\ AMENDMENT
}

\author{
Gerard N. Magliocca
}

Indiana University Robert H. McKinney School of Law

John Bingham was the architect of the rebirth of the United States following the Civil War. A leading antislavery lawyer and congressman from Ohio, Bingham wrote the most important part of the Fourteenth Amendment to the Constitution, which guarantees fundamental rights and equality to all Americans. He was also at the center of two of the greatest trials in history, giving the closing argument in the military prosecution of John Wilkes Booth's coconspirators for the assassination of Abraham Lincoln and in the impeachment of President Andrew Johnson. And more than any other man, Bingham played the key role in shaping the Union's policy towards the occupied ex-Confederate States, with consequences that still haunt our politics. Drawing on his personal letters and speeches, the book traces Bingham's life from his humble roots in Pennsylvania through his career as a leader of the Republican Party. I argue that Bingham and his congressional colleagues transformed the Constitution that the Founding Fathers created, and did so with the same ingenuity that their forbears used to create a more perfect union in the 1780s. 